\title{
A new formulation for lightweight oil well cement slurry using a natural pozzolan
}

\author{
Omid-Ali Larki ${ }^{1}$, Saeid Norouzi Apourvari ${ }^{1^{\circledR}} *$, Mahin Schaffie ${ }^{1}$, Reza Farazmand ${ }^{2}$ \\ ${ }^{1}$ Department of Petroleum Engineering, Shahid Bahonar University of Kerman, Kerman, Iran \\ ${ }^{2}$ Kerman Cement Industries Group, Kerman, Iran
}

(Received March 18, 2019; revised May 6, 2019; accepted May 7, 2019; available online May 15, 2019)

\section{Citation:}

Larki, O., Norouzi Apourvari, S., Schaffie, M., Farazmand, R. A new formulation for lightweight oil well cement slurry using a natural pozzolan. Advances in Geo-Energy Research, 2019, 3(3): 242-249, doi: 10.26804/ager.2019.03.02.

\section{Corresponding author:}

*E-mail: snorouzi@uk.ac.ir

Keywords:

Fluid loss

natural pozzolan

lightweight cement slurry

drilling cement

cementing operation

\begin{abstract}
:
Fluid loss during cementing operation in depleted reservoirs or deep wells of reservoirs with low breakdown pressure is a major concern for maintaining well integrity. This issue is usually handled by reducing the weight of cement slurry. Although various slurry formulations were proposed during the last decade, the cost and availability of required additives is still a concern, especially when the oil price is low. The objective of this study is to make lightweight cement slurry with a density of $105 \mathrm{lb} / \mathrm{ft}^{3}$, using the combination of natural pozzolan and API class G cement. This study proposes a new lightweight cement formulation based on the optimum amount of a natural pozzolan and other additives. Based on the results of 24-hour compressive strength tests and free water volume, an optimum $30 \%$ of cement powder was replaced with pozzolan. Addition of more pozzolan into the slurry reduces its pumping even at room temperature. The bottom-hole condition was simulated by increasing the temperature to $150^{\circ} \mathrm{F}$, and chemical additives were used to maintain the rheological properties of this slurry. Fluid loss control agent, dispersant and retarder were used at optimum values $0.5,0.08$ and 0.05 (\% $\%$ boc), respectively. The compressive strength of the cement rock was monitored at 3, 7 and 30 days, reaching to $3,528 \mathrm{lb} / \mathrm{in}^{2}$ after 30 days.
\end{abstract}

\section{Introduction}

Cementing operation is one of the most sensitive and most important stages in the drilling and completion of oil and gas wells (Velayati et al., 2015). Failure in this operation could endanger the production from a well, and the resulting financial damage would be irreversible. Fluid loss is a common problem during drilling and cementing stages in depleted reservoirs or reservoirs with low breakdown pressure (Mehrabian and Abousleiman, 2017; Wang et al., 2017). It is advisable to reduce the hydrostatic pressure of the slurry column to prevent formation breakage and slurry loss. The reduction of the hydrostatic pressure of the slurry column can be accomplished by three approaches including multi-stage cementing, lightweight or ultra-lightweight cement slurry.

In the multi-stage cementing technique, cement job is completed in several steps, so the hydrostatic pressure of the slurry column on the formation decreases. The disadvantage of this technique is increasing in rig time, and later remedial works might also be required (Elmarsafani et al., 2007). Moreover, the multi-stage cement tool acts as a weak point in the cementing and could cause leakage in the casing (Mukhalalaty et al., 1999).

Portland cement is the main constituent of almost all drilling cement. It could be modified easily by proportionating its raw materials and changing their combination process. The type of cement produced is classified as type I, II, III, or $\mathrm{V}$ white cement based on American Society for Testing and Materials (ASTM) or class A, C, G or $\mathrm{H}$ based on American Petroleum Institute (API). The oil industry often purchases cement manufactured in accordance with API classification as published in API Spec 10A. As for class G, no additions other than calcium sulfate or water should be blended with clinker cement. Class $\mathrm{G}$ is available in moderate sulfateresistant (MSR) and high sulfate-resistant (HSR) grades. A comprehensive discussion on properties of cement covered by API specification could be found in Smith (1990).

While a typical API class G cement slurry has a weight of $118 \mathrm{lb} / \mathrm{ft}^{3}$, lightweight cement slurry weighs $90-110 \mathrm{lb} / \mathrm{ft}^{3}$. The weight of cement slurry decreases by reducing the weight of either the liquid phase or the solid phase. The simplest way to decrease the weight of the cement slurry is to add water into it, but this excess water will dilute the slurry, causing the solid 
particles to separate and settle down. It also could reduce the compressive strength of the resulting cement rock. Therefore, this method is not reasonable, and it is suggested that other methods be used (Mata and Calabayan, 2016).

For lightening the cement slurry, oil-based fluids, waterextending additives, and lightweight additives can be used. In the first method, a liquid hydrocarbon such as kerosene is used and the light slurry is made using emulsification of hydrocarbon liquid in water and mixing it with cement. While the existence of oil in these slurries, improves the flowing property, the need for special tools limits the use of these slurries (Dumbauld et al., 1956). Gilsonite is a solid lightweight hydrocarbon, which could be used for reducing the weight of cement slurry. Since the Gilsonite slurry uses less water compared to other weighing slurries, the compressive strength of this slurry is higher. Gilsonite has a melting point in the range of $385-525{ }^{\circ} \mathrm{F}$. Therefore, it can not be used in wells that have the potential to implement heat recovery techniques (Slagle and Carter, 1959).

Water-extending additives are substances that absorb a lot of water, causing the slurry to become lighter. The lowest density that can be obtained by using water-extending additives, while the cement has acceptable properties, is $93.5 \mathrm{lb} / \mathrm{ft}^{3}$ (Kulakofsky et al., 2011). The use of water-extending additives for making ultra-lightweight cement slurry could reduce the compressive strength of the cement rock (Slagle and Carter, 1959). Bentonite is one of the water-extending materials which has been widely used in drilling mud formulation and could also be used to lighten drilling cement slurry. Since bentonite is capable of absorbing relatively high water content, it decreases the density of the slurry and increases its volume. Low resistance to detrimental downhole conditions such as corrosive water and high temperatures, could be considered as a disadvantage of bentonite slurry (Slagle and Carter, 1959).

Pozzolanic cement, hollow glass sphere (HGS) cement, and foam cement are some other innovations for lightening cement slurry, which could reduce loss circulation in depleted fields or in filed with low fracture gradient (Liu et al., 2018). Wang and coworkers (Wang et al., 2017) developed a novel selfgenerating nitrogen foam cement to prevent lost circulation. The proposed formulation was tested in a field and promising results were obtained. In another study, Wang et al. (2015) used a hydrophilic fiber to reinforce an ultralow density slurry, formulated by hollow glass sphere and class G cement. As observed by these researchers, this combination solved the lost circulation in cementing coal-bed methane wells.

Pozzolans are a broad class of inorganic siliceous and aluminous materials which upon reaction with calcium hydroxide generated during the cement hydration process could produce cementitious materials (Kutchko et al., 2009). Although the use of pozzolanic materials dates back many hundreds of years ago by ancient Romans and Greeks, their commercial use as an additive to Portland cement was started 50 years ago (Smith, 1956; Smith, 1990). The benefit of Portland-amended cement is twofold. The addition of pozzolan into Portland cement can not only reduce the cement slurry density, the initiation of pozzolanic reactions under long curing time also makes a cement rock very resistant to corrosive and high- temperature conditions (Slagle and Carter, 1959; Brandle et al., 2010; Zhang et al., 2014; Bihua et al., 2018). Different pozzolanic materials have been successfully used in the concrete composition. In a study by Ahmad et al. (2008), Palm Oil Fuel Ash (POFA), fly ash and Quarry dust, as three pozzolanic materials, were used in concrete and results were compared with a control sample. Based on their observations, 15\% replacement of Portland cement with pozzolanic materials showed the best results and compressive strength of 6,527 $\mathrm{lb} / \mathrm{in}^{2}$ (45 MPa) after 28 days of curing were achieved. The application of POFA to reinforce class $\mathrm{G}$ cement for drilling and completion operations was recently tested by Abid et al. (2019). As observed by these researchers, POFA could improve the workability of cement without disturbing the rheology of the cement slurry.

Fly ash is a synthetic pozzolan that has been used for a long time in the oil industry to lighten cement slurry (Fasesan et al., 2005). Since this material is a by-product of the thermal coal-fired power plants, its use is limited to countries with such industries. Volcanic ash is a natural pozzolan that could be found in most parts of the world. Natural pozzolan has been widely used in the construction industry, but its use in lightweight drilling cement slurries is very limited. It is partly due to the adverse effect of pozzolan addition on the rheological properties of the cement slurry. The main objective of this study is to formulate optimized cement slurry with a weight of $105 \mathrm{lb} / \mathrm{ft}^{3}$ using a natural pozzolan while maintaining required rheological properties.

\section{Materials and methods}

\subsection{Drilling cement}

In this study, API class G cement with high resistance to sulfates, produced by Kerman Cement Factory, was used. Its physical properties and chemical analysis are presented in Tables 1 and 2, respectively.

\subsection{Sirjan natural pozzolan}

Natural pozzolan was acquired from a mine located near Sirjan in Kerman province ( $29^{\circ} 53^{\prime} 39.0^{\prime \prime}$ N, $\left.56^{\circ} 04^{\prime} 57.0^{\prime \prime} \mathrm{E}\right)$. This mine is located on the volcanic belt of Urmia-Bazman and consists mainly of volcanic, igneous and sedimentary rocks of Tertiary age (less than 60 million years old). The length of the belt is about 1,500 kilometers and its width is from 100 to 120 kilometers, which starts from the Sultan's mountains in Pakistan and continues to Armenia. Sirjan pozzolan is a type of crystalline tuff with porphyritic and glassy texture. Plagioclase, amphibole, biotite and quartz crystals are observed in it.

The chemical analysis of this pozzolan is given in Table 3 . According to Table 3 and ASTM C618-08a (2008), this po-

Table 2. Chemical analysis of API class G cement, used in this study.

\begin{tabular}{llllll}
\hline \multicolumn{2}{c}{$\%$ C3S } & \multicolumn{2}{c}{$\%$ C3A } & \multicolumn{2}{c}{$\%$ SO3 } \\
\hline Standard & Test & Standard & Test & Standard & Test \\
$48-46$ & 56.5 & $\leqslant 3$ & 2.3 & $\leqslant 3$ & 1.58 \\
\hline
\end{tabular}


Table 1. Physical specifications of API class G cement, used in this study.

\begin{tabular}{|c|c|c|c|c|c|c|c|}
\hline \multicolumn{4}{|c|}{ 8-hour compressive strength $\left(\mathrm{lb} / \mathrm{in}^{2}\right)$} & \multirow{2}{*}{\multicolumn{2}{|c|}{ Free water $(\mathrm{ml})$}} & \multirow{2}{*}{\multicolumn{2}{|c|}{ Density $\left(\mathrm{g} / \mathrm{cm}^{3}\right)$}} \\
\hline & $00^{\circ} \mathrm{F}$ & @ & $40{ }^{\circ} \mathrm{F}$ & & & & \\
\hline Standard & Test & Standard & Test & Standard & Test & Standard & Test \\
\hline$\geqslant 300$ & 561 & $\geqslant 1,500$ & 2018 & $\leqslant 3.5$ & 1.55 & $3.1-3.25$ & 3.1424 \\
\hline
\end{tabular}

Table 3. Chemical analysis of Sirjan natural pozzolan.

\begin{tabular}{lllllllllll}
\hline Components & L.O.I & $\mathrm{SiO}_{2}$ & $\mathrm{Al}_{2} \mathrm{O}_{3}$ & $\mathrm{Fe}_{2} \mathrm{O}_{3}$ & $\mathrm{CaO}$ & $\mathrm{MgO}$ & $\mathrm{SO}_{3}$ & $\mathrm{Na}_{2} \mathrm{O}$ & $\mathrm{K}_{2} \mathrm{O}$ & $\mathrm{Cl}$ \\
\hline Percent (\%) & 7.46 & 59.22 & 16.74 & 4.00 & 6.85 & 0.95 & 0.060 & 3.46 & 1.91 & 0.036 \\
\hline
\end{tabular}

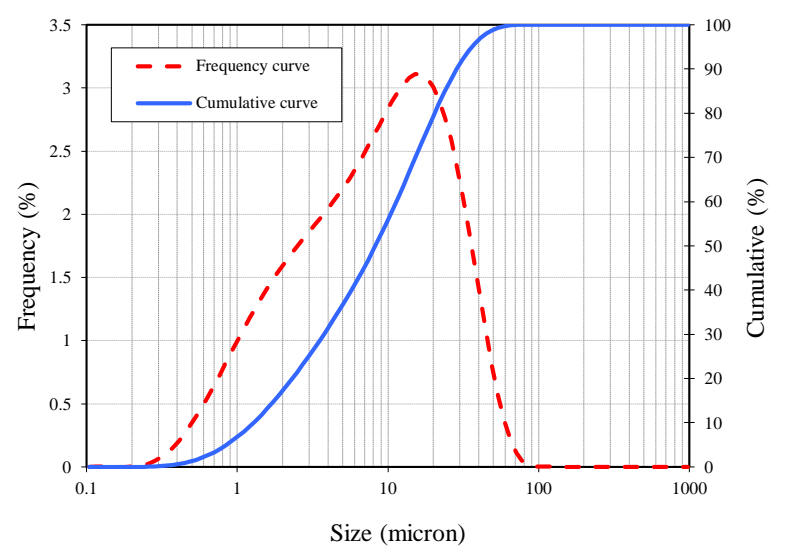

Fig. 1. Grain size distribution of Sirjan pozzolan.

zzolan is categorized as a natural pozzolan.

Also, the grain size distribution of Sirjan pozzolan, used in this study, is shown in Fig. 1. The grains have a geometric mean of $7.31 \mu \mathrm{m}$, with uniformity of 1.05 and specific surface area of $16,906.97 \mathrm{~cm}^{2} / \mathrm{cm}^{3}$.

\subsection{Chemical additives}

Retarder, dispersant and fluid loss control additives were used in cement slurry formulation. Their characteristics are presented in Table 4.

\subsection{Experimental procedure}

\subsubsection{Sampling and preparation of Sirjan pozzolan}

Sampling from pozzolan depot was performed according to ASTM D75/D75M-14 (2014). The reference sample was first crushed using a jaw crusher. Since the reference sample was more than the amount required for the tests, the sample weight was reduced according to a standard procedure. There are three methods of weight reduction. Here, the quartering method was used according to ASTM C702/C702M-11 (2011). The sample obtained at the end of this method was placed in an oven at $230{ }^{\circ} \mathrm{F}$ for 24 hours to dry. It was then ground with a vibratory disc mill RS 100, made by Retsch, and was passed through a 90-micron sieve.
Table 4. Specifications of chemical additives used in this study.

\begin{tabular}{lll}
\hline Additive & COmmercial code & Density $\left(\mathrm{g} / \mathrm{cm}^{3}\right)$ \\
\hline Retarder & JR-120 & 1.2 \\
Dispersant & O-CFR 4 & 1.4 \\
Fluid loss control & FLC 320 & 1.4 \\
\hline
\end{tabular}

\subsubsection{Density measurement of solids}

It is necessary to measure the density of the components of the slurry for calculating its wieght. At first, cement powder was passed through a US mesh 20, and then the density of this cement and natural pozzolan was measured using kerosene in compliance with ASTM C188-16 (2016).

\subsubsection{Slurry preparation}

Material balance calculations were made to determine the weight of each material in the slurry, based on the standard volume of the $600 \mathrm{ml}$. slurry (API Spec 10A, 2010; API RP $10 \mathrm{~B}, 2013)$. The cement powder was first sieved using US mesh 20, then mixed with natural pozzolan and blended until a homogeneous solid mixture was obtained. Chemical additives were added into the water to make the liquid phase. After that, the solid phase (cement powder and Sirjan pozzolan) was added into the liquid phase while mixing at $4,000 \mathrm{rpm}$ in less than 15 seconds using a special mixer (Chandler Engineering). The blend was finally mixed for 35 seconds at $12,000 \mathrm{rpm}$.

\subsubsection{Free water test}

When the slurry is left to the static state, the water may separate from the lower parts of the slurry column and migrate upward. This separation can damage the zonal isolation, which is one of the important goals of cement job (Al-Yami et al., $2008,2010)$. In this test, in order to simulate the dynamic conditions of the cement replacement inside the well, the slurry is conditioned by an atmospheric pressure consistometer for 30 minutes at $80{ }^{\circ} \mathrm{F}$. After that, in accordance with API standard, the slurry is poured into a $250 \mathrm{ml}$ cylinder and the separated water from the slurry is measured after 2 hours (API RP 10B, 2013). 


\subsubsection{Rheology test}

The slurry was conditioned in an atmospheric pressure consistometer at $150{ }^{\circ} \mathrm{F}$, before measuring rheological parameters using a standard viscometer (model 3,500, Chandler Engineering). In accordance with API standard, the plastic viscosity and yield point values were calculated using relations 1 and 2, respectively (API RP 10B, 2013):

$$
\mu_{p}=1.5 \cdot F \cdot\left(\theta_{300}-\theta_{100}\right)
$$

where $\mu_{p}$ is plastic viscosity, $F$ is spring factor (dimensionless), $\theta_{300}$ is dial reading at the rotational speed of $300 \mathrm{rpm}$ (degree) and 100 is dial reading at the rotational speed of $\theta_{100}$ rpm (degree).

$$
\tau_{0}=F \cdot \theta_{300}-\mu_{p}
$$

here, $\tau_{0}$ is yield point $\left(\mathrm{lb} / 100 \mathrm{ft}^{2}\right)$.

\subsubsection{Compressive strength}

The prepared slurry was poured into standard $2 \times 2 \times$ 2 inch cubic molds and was cured at $140{ }^{\circ} \mathrm{F}$ in accordance with API standard (API Spec 10A, 2010). After a specified time, which depends on the aim of the experiment, cement cubes were crushed under a hydraulic press and the uniaxial compressive strength for these cubes was calculated. A Toni Technik (model Tonizem) hydraulic press machine was used for crushing cement rock cubes. In this study, 8-hour, 24-hour, 3-day, 7-day and 30-day compressive strength was measured on different cement blocks.

\section{Results and discussions}

\subsection{The density of cement powder and pozzolan}

The density test results for cement powder and Sirjan pozzolan are given in Table 5. According to Table 5, the pozzolan density is less than that for cement powder. Therefore, it is expected that slurry density decreases when replacing a part of cement powder with Sirjan pozzolan.

Based on the results obtained, the density of the Sirjan natural pozzolan $\left(2.43 \mathrm{~g} / \mathrm{cm}^{3}\right)$ is almost the same as the density of fly ash $\left(2.5 \mathrm{~g} / \mathrm{cm}^{3}\right)$ used by Purvis and Merritt (2003).

\subsection{The optimum amount of Sirjan pozzolan}

The amounts of 10, 30, 50 and $77 \%$ bwoc (based on the weight of cement) from pozzolan were mixed with drilling cement powder for making slurry at $105 \mathrm{lb} / \mathrm{ft}^{3}$. When the amount of pozzolan was $77 \%$ bwoc or $50 \%$ bvob (based on the volume of bulk solid), the slurry was gelled, implying that adding this amount of pozzolan or more will damage the rheology of the cement slurry. Purvis and Merritt (2003) used

Table 5. Density of solid materials.

\begin{tabular}{ll}
\hline Solid Materials & Density $\left(\mathrm{g} / \mathrm{cm}^{3}\right)$ \\
\hline API class G cement powder & 3.14 \\
Sirjan natural pozzolan & 2.43 \\
\hline
\end{tabular}

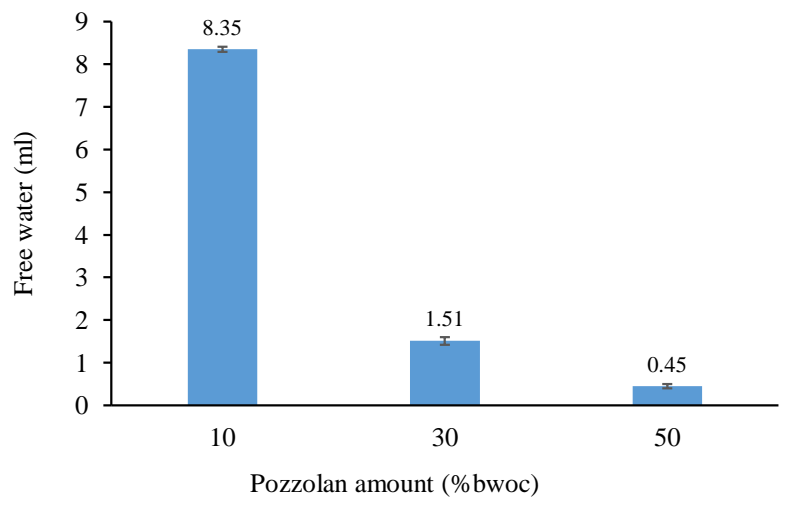

Fig. 2. Free water volume of pozzolanic slurries.

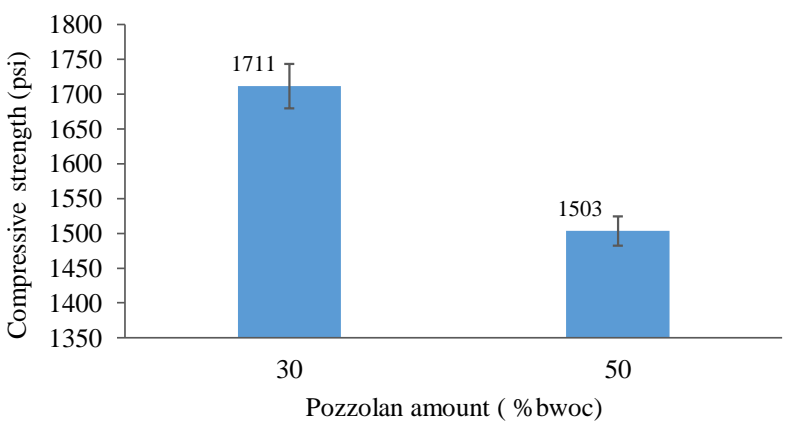

Fig. 3. 24-hour compressive strength of pozzolanic slurries at $100^{\circ} \mathrm{F}$.

more than $50 \%$ bvob of fly ash to make slurry with a density of nearly $105 \mathrm{lb} / \mathrm{ft}^{3}$. This difference could be mainly attributed to the difference in the shape of the particles. Fly ash particles are spherical, which helps to facilitate slurry flow and improve rheology. Therefore, using its large amounts in the slurry does not cause much damage to rheology. However, the particles of natural pozzolan, used in this study, have irregular shapes and that is might be the reason why slurry containing $77 \%$ bwoc of pozzolan was rejected.

The free water test was then carried out for pozzolanic slurry at $80{ }^{\circ} \mathrm{F}$ and the results are shown in Fig. 2. As shown, the free water volume for slurry containing $10 \%$ pozzolan was $8.35 \mathrm{ml}$, while the acceptable free water volume for API class $\mathrm{G}$ cement is less than $3.5 \mathrm{ml}$, so this composition was also rejected. Based on different applications, the acceptable free fluid could change; however, excessive free water damages the quality of the cement sheath. In the following, a uniaxial compressive strength test was performed for the two remaining compounds.

Pozzolanic slurries were cured for 24 hours at $140{ }^{\circ} \mathrm{F}$ and the resulting cement rock was crushed by a hydraulic press. The compressive strength results of these slurries are shown in Fig. 3. Slurry containing 30\% of pozzolan has higher compressive strength, so it was selected as an optimal amount.

The cement sheath should be strong enough to hold the casing. While a compressive strength of $100 \mathrm{lb} / \mathrm{in}^{2}$ is usually enough to keep casings in place, $500 \mathrm{lb} / \mathrm{in}^{2}$ is mostly considered as a criterion for casing support (Al-Yami et 
Table 6. Rheology results of cement slurry at $150^{\circ} \mathrm{F}$.

\begin{tabular}{lllllll}
\hline $\begin{array}{l}\text { Pozzolan } \\
(\% \text { bwoc })\end{array}$ & $\begin{array}{l}\text { Cement } \\
(\% \text { bwoc })\end{array}$ & $\begin{array}{l}\text { Fluid loss control } \\
(\% \text { bwoc })\end{array}$ & $\begin{array}{l}\text { Retarder } \\
(\% \text { bwoc })\end{array}$ & $\begin{array}{l}\text { Dispersant } \\
(\% \text { bwoc })\end{array}$ & $\begin{array}{l}\text { Plastic viscosity } \\
(\mathrm{cp})\end{array}$ & $\begin{array}{l}\text { Yield point } \\
\left(\mathrm{lb} / 100 \mathrm{ft}^{2}\right)\end{array}$ \\
\hline 30 & 100 & 0.5 & 0.05 & 0.08 & 30 & 6 \\
\hline
\end{tabular}

Table 7. Weight percent of solids in pozzolanic and neat slurries.

\begin{tabular}{llllll}
\hline Slurry number & $\begin{array}{l}\text { API class G cement } \\
(\% \text { bwoc })\end{array}$ & $\begin{array}{l}\text { Sirjan pozzolan } \\
(\% \text { bwoc })\end{array}$ & $\begin{array}{l}\text { Dispersant } \\
(\% \text { bwoc })\end{array}$ & $\begin{array}{l}\text { Retarder } \\
(\% \text { bwoc })\end{array}$ & $\begin{array}{l}\text { Fluid loss control } \\
(\% \text { bwoc })\end{array}$ \\
\hline 1 & 100 & 0 & 0 & 0 & 0 \\
2 & 100 & 30 & 0 & 0 & 0 \\
3 & 100 & 30 & 0.08 & 0.05 & 0.5 \\
\hline
\end{tabular}

al., 2008) and a permission to continue drilling operations. Based on Fig. 3, the 24-hour compressive strength of the Pozzolanic slurry exceeds the proposed values of 100 and 500 $\mathrm{lb} / \mathrm{in}^{2}$. This indicates that the pozzolanic slurry has a sufficient compressive strength to hold the casing in place.

Purvis and Merritt (2003) and Fasesan et al. (2005) developed cement slurries with densities of about $105 \mathrm{lb} / \mathrm{ft}^{3}$ using 50 \%bvob or more of fly ash. In this study, the cement slurry with the same density was made using $30 \%$ bwoc (or $28 \%$ bvob) of natural pozzolan. Since the density of natural pozzolan and fly ash are almost equal, the reason for the difference in the used volume of these materials is the higher water absorption of natural pozzolan compared to fly ash.

The slurry weight and its rheology are two of the most crucial parameters in well cementing job. Since rheology of the slurry is sensitive to the interaction of the additives, the rheological control could be more difficult than weight control. The lead cement slurry should have enough viscosity to move the mud from the annulus upward. For cement slurry with specified viscosity, the additives and size of cement particles are effective.

Based on our observations, the slurry containing $30 \%$ of the pozzolan was gelled at $150{ }^{\circ} \mathrm{F}$, so it was not possible to measure its rheological properties. This problem was resolved with the help of chemical additives. The results of the slurry rheology along with the chemical additive used are given in Table 6. According to Table 6, the values of 0.5, 0.05 and 0.08 $\%$ bwoc from fluid loss control, retarder and dispersant agent were added to slurry, respectively. These amounts are optimum and were obtained through intensive laboratory measurements. Plastic viscosity and yield point for this slurry were measured $30 \mathrm{cp}$ and $6 \mathrm{lb} / 100 \mathrm{ft}^{2}$, respectively.

Three samples were prepared to compare free water and compressive strength of pozzolanic slurry with that of neat slurry. The details of these three slurries are reported in Table 7.

The results of free water content and 24-hour compressive strength at $140{ }^{\circ} \mathrm{F}$ for these samples are shown in Fig. 4 and Fig. 5, respectively. According to Fig. 4, the free water volume of the pozzolanic slurry is similar to that of neat cement slurry, but the amount of free water was increased with the addition

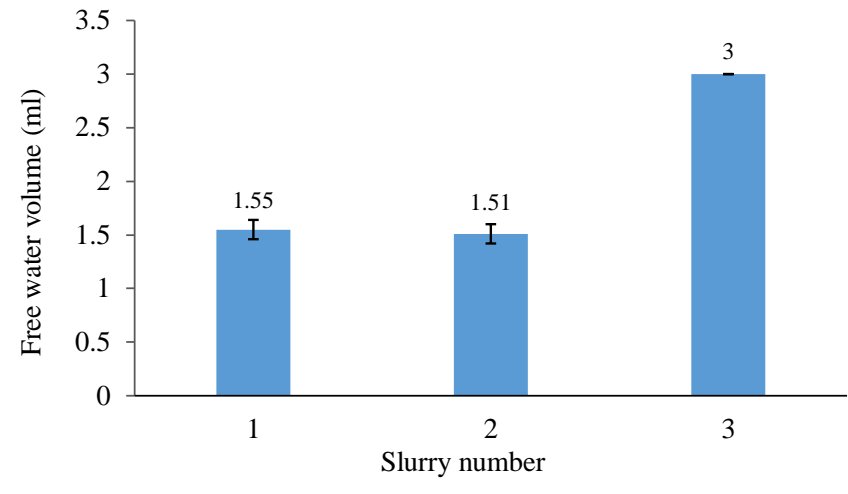

Fig. 4. Comparison of free water content between pozzolanic slurry 2 (30 \%bowc pozzolan without rheology-control additives) and slurry 3 (30\%bwoc pozzolan with rheology-control additives) and neat slurry 1.

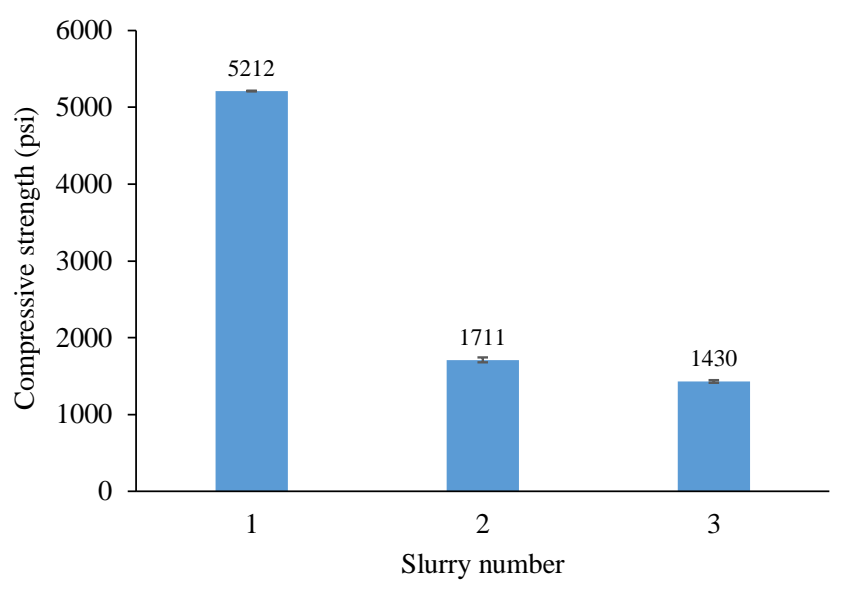

Fig. 5. Comparison of compressive strength between pozzolanic slurry 2 (30 \% bowc pozzolan without rheology-control additives) and slurry 3 (30 \% bwoc pozzolan with rheology-control additives) and neat slurry 1.

of chemical additives in slurry number 3 . This is mainly due to the lower water absorption of chemical additives compared to the natural pozzolan. Although the amount of free water increased, the slurry is still in the standard range of free water.

According to Fig. 5, the compressive strength of a pozzolanic slurry with a weight of $105 \mathrm{lb} / \mathrm{ft}^{3}$ is lower than neat 
API class $\mathrm{G}$ cement slurry. In pozzolanic slurry, the amount of drilling cement is about half of that in the neat slurry, making the reduction of compressive strength predictable. This conclusion is in agreement with the study of Brandl et al. (2010), who reported reduction in the compressive strength of fly ash contained cement slurry. Moreover, by adding chemical additives, the compressive strength of the pozzlanic slurry was decreased more, which is due to the retarding effect of the chemical additives.

\subsection{Long-term compressive strength of pozzolanic and neat slurry}

The strength development of the cement rock will not end with thickening of the slurry, but will continue for months, even years after that. In order to better understand the behavior of compressive strength at more than 24 hours, it was decided to examine the strength of the cement rock after 3,7 , and 30 days in compliance with studies performed by (Benge et al., 1982; Harms and Sutton, 1983; De Rozieres and Ferriere, 1991; Al-Yami et al., 2010, 2012).

The hydrated calcium silicate and the portlandite (Calcium hydroxide) are mainly formed during the cement hydration period (reaction 3 and 4).

$$
\begin{gathered}
2 \mathrm{C}_{3} \mathrm{~S}+6 \mathrm{H} \rightarrow \mathrm{C}_{3} \mathrm{~S}_{2} \mathrm{H}_{3}+3 \mathrm{CH} \\
2 \mathrm{C}_{3} \mathrm{~S}+4 \mathrm{H} \rightarrow \mathrm{C}_{3} \mathrm{~S}_{2} \mathrm{H}_{3}+\mathrm{CH}
\end{gathered}
$$

Hydrated calcium silicate (C-S-H) is responsible for the strength of the cement rock. Portlandite, on the other hand, not only does not contribute to the strength of the cement rock, it is also a weak point in the cement matrix. Pozzolanic substances have $\mathrm{SiO}_{2}$ (and $\mathrm{Al}_{2} \mathrm{O}_{3}$ ) compounds that react with portlandite and form further $\mathrm{C}-\mathrm{S}-\mathrm{H}$ phases (or C-A-S-H phases), which increases the strength of the cement rock (reaction 5).

$$
\mathrm{Ca}(\mathrm{OH})_{2}+\mathrm{SiO}_{2}\left(\mathrm{Al}_{2} \mathrm{O}_{3}\right) \rightarrow \mathrm{C}-\mathrm{S}-\mathrm{H}(\mathrm{C}-\mathrm{A}-\mathrm{S}-\mathrm{H}) \text { phases }
$$

Based on reactions 3, 4 and 5, while cementitious reactions are first initiated, pozzolanic reactions will occur later. In other words, the pozzolanic reactions show their effects better over time (Brandle et al., 2011).

To better understand the behavior of pozzolan-amended cement over time, a comparison on compressive strength of neat and pozzolanic cement was performed and the result is shown in Fig. 6. The amount of cement used in the neat slurry is greater than the pozzolanic slurry. Therefore, cementitious reactions will be higher in the neat slurry. For the same reasons and according to Fig. 6, in the first 24 hours, the strength development rate of neat slurry is greater than that of the pozzolanic slurry. After that, due to the activation of the pozzolanic reactions, the difference in the development rate between the two cement slurries is decreased.

More detailed results of long-term compressive strength are reported in Table 8. As shown, after three days, the compressive strength of the pozzolanic slurry reaches 2,589

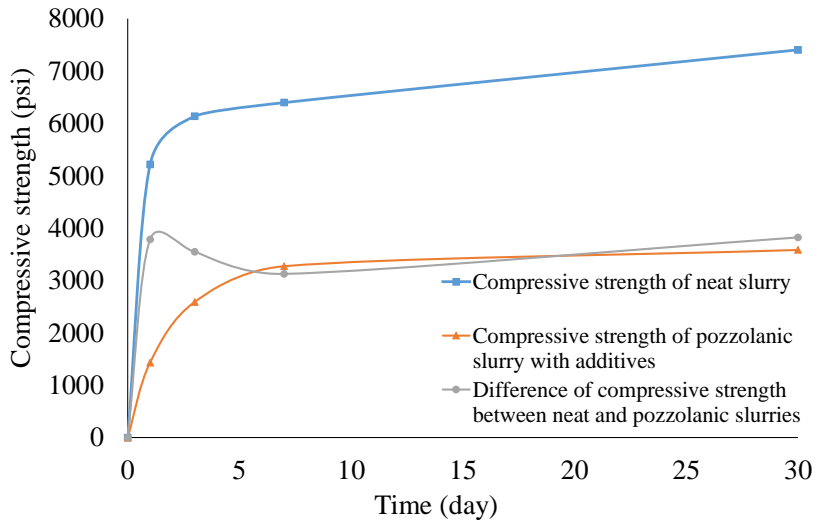

Fig. 6. Long-term compressive strength of pozzolanic and neat slurries.

Table 8. The results of long-term compressive strength $\left(\mathrm{lb} / \mathrm{in}^{2}\right)$.

\begin{tabular}{lllll}
\hline Slurry number & 1 day & 3 days & 7 days & 30 days \\
\hline 1 & 5,212 & 6,135 & 6,396 & 7,404 \\
3 & 1,430 & 2,589 & 3,271 & 3,582 \\
\hline
\end{tabular}

$\mathrm{lb} / \mathrm{in}^{2}$, which is higher than what standard requires.

Brandl et al. (2010) reported a three-day compressive strength of $2,529 \mathrm{lb} / \mathrm{in}^{2}$ for a slurry containing fly ash with the same density to the pozzolan we used here. Curing temperature is one of the important parameters in the compressive strength of cement slurry so that, with other parameters remaining constant, the compressive strength of the slurry increases with increasing temperature. Although the curing temperature for pozzolanic slurry was $40^{\circ} \mathrm{F}$ less than the slurry containing the fly ash made by Brandl et al. (2010), the compressive strength of the two slurries is similar. Safe production of wells after perforation requires the final compressive strength of at least $1,500 \mathrm{lb} / \mathrm{in}^{2}$ under bottomhole condition (Putra et al., 2016). As reported in Table 8, the proposed pozzolanic slurry has reached to this required strength.

\section{Conclusions}

In this study, we tried to design a lightweight cement slurry with a weight of $105 \mathrm{lb} / \mathrm{ft}^{3}$ using a natural pozzolan. The main findings obtained are as follow:

- The optimal amount of Sirjan natural pozzolan for making lightweight cement slurry with a weight of $105 \mathrm{lb} / \mathrm{ft}^{3}$ is $30 \%$ bwoc (or $28 \%$ bvob).

- The excessive addition of natural pozzolan to slurry with specified weight results in more water absorption and will reduce pumping of the slurry.

- The lightweight pozzolanic slurry has a lower compressive strength compared to the normal API class G cement slurry.

- When using pozzolanic slurry at the circulating temperatures of 150 or more, it is essential to use chemical additives to improve rheology.

- In the short term, the compressive strength development 
for pozzolanic slurry is less than the neat API class G cement slurry, but over time, due to the activation of pozzolanic reactions, this difference is reduced.

- The replacement of a part of cement powder with a natural pozzolan in slurry composition could be considered as an important step in reducing costs and more importantly in protecting the environment by reducing the $\mathrm{CO}_{2}$ emission.

\section{Nomenclature}

\section{Abbreviations}

API $=$ American Petroleum Institute

ASTM $=$ American Society for Testing and Materials

bvob $=$ based on volume of bulk

bwoc $=$ based on weight of cement

HGS $=$ Hollow Glass Sphere

HSR $=$ High Sulfate-Resistant

MRS $=$ Moderate Sulfate-Resistant

POFA $=$ Palm Oil Fuel Ash

\section{Variables}

$\mu_{p}=$ Plastic viscosity, $\mathrm{cp}$

$\theta_{300}=$ Dial reading at the rotational speed of $300 \mathrm{rpm}$, degree

$\theta_{100}=$ Dial reading at the rotational speed of $100 \mathrm{rpm}$, degree

$\mathrm{F}=$ Spring factor, dimensionless

$\tau_{0}=$ Yield point, $\mathrm{lb} / 100 \mathrm{ft}^{2}$

\section{Acknowledgments}

The authors would like to thank Kerman cement factory for its lab equipment and material. Special thanks go to Masoud Naeeb Lee from the Kerman factory lab for his guidance.

Open Access This article is distributed under the terms and conditions of the Creative Commons Attribution (CC BY-NC-ND) license, which permits unrestricted use, distribution, and reproduction in any medium, provided the original work is properly cited.

\section{References}

Abid, K., Gholami, R., Tiong, M., et al. A pozzolanic supplementary material to reinforce class $\mathrm{G}$ cement used for drilling and completion operations. J. Pet. Sci. Eng. 2019, 177: 79-92.

Ahmad, M.H., Omar, R.C., Malek, M.A., et al. Compressive strength of palm oil fuel ash concrete. In Proceedings of International Conference on Construction and Building Technology, Kuala Lumpur, Malaysia, 16-20 June, 2008.

Al-Yami, A.S., Al-Shehri, D.A., Al-Saleh, S., et al. Long-term evaluation of low-density cement, based on hollow glass microspheres, aids in providing effective zonal isolation in hp/ht wells: Laboratory studies and field applications. Paper SPE113138 Presented at SPE Western Regional and Pacific Section AAPG Joint Meeting, Bakersfield, California, 29 March-4 April, 2008.

Al-Yami, A.S., Nasr-El-Din, H.A., Al-Humaidi, A.S., et al. Evaluation and optimization of low-density cement:
Laboratory studies and field application. SPE Drill. Completion 2010, 25(1): 70-89.

Al-Yami, A.S., Yuan, Z., Schubert, J. Failure probability with time under different operational conditions for low-density system based on hollow microspheres supported by long term lab studies and field cases. Paper SPE159141 Presented at SPE Asia Pacific Oil and Gas Conference and Exhibition, Perth, Australia, 2224 October, 2012.

API RP 10B-2: Recommended Practice for Testing Well Cements. Second Edition. April, 2013.

API Spec 10A: Specification for Cements and Materials for Well Cementing. Twenty-Fourth Edition. December, 2010.

ASTM Designation C618-08a, Standard Specification for Coal Fly Ash and Raw or Calcined Natural Pozzolan for Use in Concrete, 2008.

ASTM Designation C702/C702M-11, Standard Practice for Reducing Samples of Aggregate to Testing Size, 2011.

ASTM Designation D75/D75M 14, Standard Practice for Sampling Aggregates, 2014.

ASTM Designation C188-16, Standard Test Method for Density of Hydraulic Cement, 2016.

Benge, O.G., Spangle, L.B., Sauer, Jr.C.W. Foamed cementsolving old problems with a new technique. Paper SPE11204 Presented at SPE Annual Technical Conference and Exhibition, New Orleans, Louisiana, 1 January, 1982.

Brandl, A., Bray, W., Doherty, D.R. Technically and economically improved cementing system with sustainable components. Paper SPE136276 Presented at IADC/SPE Asia Pacific Drilling Technology Conference and Exhibition, Ho Chi Minh City, Vietnam, 1-3 November, 2010.

Brandl, A., Cutler, J., Seholm, A., et al. Cementing solutions for corrosive well environments. SPE Drill. Completion 2011, 26(2): 208-219.

De Rozieres, J., Ferriere, R. Foamed-cement characterization under down hole conditions and its impact on job design. SPE Prod. Eng. 1991, 6(3): 297-304.

Dumbauld, G.K., Brooks, Jr.F.A., Morgan, B.E., et al. A lightweight, low water-loss, oil-emulsion cement for use in oil wells. Pet. Trans. 1956, 207: 99-104.

Elmarsafawi, Y.A., Warman, R., Assad, A., et al. Cementing a producing formation with low-fracture-pressure gradient in Wafra Field, Kuwait. Paper SPE107047 Presented at Asia Pacific Oil and Gas Conference and Exhibition, Jakarta, Indonesia, 30 October-1 November, 2007.

Fasesan, O.A., Heinze, L.R., Walser, D.W. Enhanced properties and cost-effective application with incremental improvements in 50:50 Poz cementing. Paper SPE94327-MS Presented at Canadian International Petroleum Conference, Calgary, Alberta, 7-9 June, 2005.

Harms, W.M., Sutton, D.L. Ultralow-density cementing operations. J. Pet. Technol. 1983, 35(1): 61-69.

Kulakofsky, D., Faulkner, C., Williams, S., et al. New class of microsphere improves economics and allows circulation where previous designs suffered losses: A 
case history. Paper OMC-2011-083 Presented at Offshore Mediterranean Conference and Exhibition, Ravenna, Italy, 23-25 March, 2011.

Kutchko, B.G., Strazisar, B.R., Huerta, N., et al. $\mathrm{CO}_{2}$ reaction with hydrated class $\mathrm{H}$ well cement under geologic sequestration conditions: Effects of fly ash admixtures. Environ. Sci. Technol. 2009, 43(10): 3947-3952.

Liu, K., Cheng, X., Zhang, X., et al. Design of low-density cement optimized by cellulose-based fibre for oil and natural gas wells. Powder Technol. 2018, 338: 506-518.

Mata, C., Calubayan, A. Use of hollow glass spheres in lightweight cements-selection criteria. Paper SPE182399 Presented at SPE Asia Pacific Oil \& Gas Conference and Exhibition, Perth, Australia, 25-27 October, 2016.

Mehrabian, A., Abousleiman, Y. Wellbore geomechanics of extended drilling margin and engineered lost-circulation solutions. SPE J. 2017, 22(4): 1178-1188.

Mukhalalaty, T., Al Suwaidi, A., Shaheen, M. Increasing well life cycle by eliminating the multistage cementer and utilizing a lightweight high performance slurry. Paper SPE53283 Presented at Middle East Oil Show and Conference, Bahrain, 20-23 February, 1999.

Purvis, D.L., Merritt, J.W. Economic completion slurries utilized in partially depleted reservoirs. Paper SPE80942 Presented at SPE Production and Operations Symposium, Oklahoma City, Oklahoma, 23-26 March, 2003.

Putra, T., Steven, A., Wedhaswari, V.R., et al. Novel cementing solutions to impede lost circulation with highly crushresistant lightweight cement system and engineered fibers. Paper SPE182250 Presented at SPE Asia Pacific
Oil \& Gas Conference and Exhibition, Perth, Australia, 25-27 October, 2016.

Slagle, K.A., Carter, L.G. Gilsonite-a unique additive for oilwell cements. Paper API-59-318 Presented at Drilling and Production Practice, New York, USA, 1 January, 1959.

Smith, D.K. A new material for deep well cementing. Pet. Trans. 1956, 207: 59-64.

Smith, D.K. Cementing, SPE Monograph Series, Volume 4, 1990.

Velayati, A., Tokhmechi, B., Soltanian, H., et al. Cement slurry optimization and assessment of additives according to a proposed plan. J. Nat. Gas Sci. Eng. 2015, 23: 165-170.

Wang, C., Chen, X., Wang, L., et al. A novel self-generating nitrogen foamed cement: The preparation, evaluation and field application. J. Nat. Gas Sci. Eng. 2017, 44: 131-139.

Wang, C., Wang, R., Zhou, W., et al. The use of a novel spacer and ultralow-density cement system to control lost circulation in coalbed-methane wells. SPE Drill. Completion 2015, 30(1): 76-85.

$\mathrm{Xu}, \mathrm{B}$,, Yuan, B., Wang, Y. Anti-corrosion cement for sour gas $\left(\mathrm{H}_{2} \mathrm{~S}-\mathrm{CO}_{2}\right)$ storage and production of HTHP deep wells. Appl. Geochem. 2018, 96: 155-163.

Zhang, L., Dzombak, D.A., Nakles, D.V., et al. Effect of exposure environment on the interactions between acid gas $\left(\mathrm{H}_{2} \mathrm{~S}\right.$ and $\left.\mathrm{CO}_{2}\right)$ and pozzolan-amended wellbore cement under acid gas co-sequestration conditions. Int. J. Greenhouse Gas Control 2014, 27: 309-318. 